\title{
Influence of Family Type (Single /Step-Parent) and Parenting Styles (Authoritarian /Authoritative) on Adolescent's Social Behaviour in Yenagoa L.G.A. of Bayelsa State
}

\author{
Ekechukwu Rosemary Obiagaeri (Ph.D) \\ Department of Educational Psychology, Guidance and Counselling, Faculty of Education, University of Port \\ Harcourt, Rivers State, Nigeria
}

*Corresponding Author: Ekechukwu Rosemary Obiagaeri, Department of Educational Psychology, Guidance and Counselling, Faculty of Education, University of Port Harcourt, Rivers State, Nigeria

\begin{abstract}
The study focused on influence of family and parenting styles on adolescent social behavior. The study adopted an ex-post-facto design for the study. A sample of 383 respondents was used for the study. The sample size was statistically drawn using TaroYamen's formula for sample size. The researcher adopted simple random sampling technique to select 10 schools from the 18 public schools and purposive sampling technique to determine respondents for the study. Two instruments were used to collect data for the study. Parenting style Inventory II (PSI-II) developed by Darling \& Steinberg (1993) was adapted and used to collect data relating to parenting styles while Social Behaviour Inventory (SBI) developed by the researcher was used to collect data on social development of the adolescents. Data collected were answered with mean and standard deviation statistics, while the hypotheses were tested with an independent t-test. The data analyzed revealed that, family type (single/step-parent) had insignificant influence on social behavior of adolescents. Based on the findings of this study, it was recommended that, Parents ought to be educated on the importance of adopting the parenting style that would aid in promoting their children's development. Educators and counsellors could be used to give lectures during PTA meetings, Speech and Prize Giving Days, Open Days and Anniversaries to educate parents on the influence of parenting styles on children's development.
\end{abstract}

Keywords: Family Types (Single/Step-parent), Parenting Styles (Authoritarian/ Authoritative) Adolescent, Social Behaviour.

\section{INTRODUCTION}

Every child is unique in itself and has its own pace of growth and development. As the child grows up, his emotions and social functioning changes and continues till adolescence. Adolescence is that critical period of human development during which rapid biological, psychological and social changes take place. This period marks the end of childhood and sets the foundation for maturity. Adolescence is defined as the period of transition between childhood to adulthood that involves biological, cognitive, and socio-emotional changes. During this period, parents expect more self-regulation and initiative at the very time that their early teenagers are beginning to experiment with all kinds of risky behaviors (Barber, 2002). Anecdotal evidence and self-report data suggest that, children seem to become progressively self-conscious and concerned with other people's opinions as they go through puberty and the period of adolescence (Steinberg, 2011). The psychosocial context of adolescents is markedly different to that of children and adults. Relationships with peers, family and society go through distinct changes during this time. Adolescents begin to assert more autonomous control over their decisions, emotions and actions, and start to disengage from parental control. At the same time, the school context involves an intense socialization process during which adolescents become increasingly aware of the perspectives of classmates, teachers and other societal influences (Berzonsky and Adams, 2003). Right from infancy, children learn and acquire traits and behaviours that they exhibit throughout their life time. During socialization, parents and significant others in the society endeavour to form children in such a way as to make them acquire worthwhile virtues cherished by the society. Parents customarily are obligated to play this all- important role of socializing their children into their social milieu as primary agents of socialization. It is believed that 
there are some roles that are better performed by parents which children tend to accept most readily than any other person in their life. Since parental roles are essentially formative, their influence in the socialization of children cannot be over-emphasized.

Researchers are of the view that the type of family a child comes from and the parenting style of the child's parents is likely to influence the child's social behaviour (Steinberg, 2011; Olds \&Papilia, 2011; Baltus, 2012). One of the basic components of the society is the family. The family is the first institution for the socialization of the child and from where the child learns cooperation and other social skills. This is the first family unit for the child. According to Macionis \& Plummer (2007), a family unit is a social group of two or more people related by blood or adoption that usually live together. Individuals are born into a family. Eke (2000) defined a family as a social unit or group characterized by common residence, economic co-operation and reproduction. The family therefore includes adults of both sexes, two of whom maintain a socially approved sexual relationship with one or more children biologically owned or adopted.

Berndth (2007) stated that, the single parent family has been one of the fastest growing types in most parts of the world. Single parent family has come into existence as a result of divorce, dissertation, death, separation and out-of-wedlock births. Children from such families may suffer from guilt and loneliness, feelings of anger to mention a few. Young ones in single parent families' contend with intense emotions due to their parents' abrupt departure or death. For many adolescents, the absence of one of the parent's seems to have profound negative effect on them. Another family type is the stepparent family, Berndit (2007) pointed out that, this type of family comes into existence as a result of either a parent's divorce or death. He further stated that children in this type of family are found not to be well adjusted at school. They manifest behaviour problems and perform poorly at school, and their behaviour is like those of single parent families. The Children tend to react negatively if one of their divorced parents remarries and they become part of a new family described as step family. Problem arises because children at this stage of development are expected to be under authority to be carefully monitored. Also in step parent's family, monitoring is inadequate, the children suffer from a number of behavioural disorders (Berndit, 2007).

Parenting styles are persistent approaches, strategies and standards parents use in bringing up their children. They involve how parents respond to children's psychological and material needs, and what parents' demands from their children. Parenting styles are unique and evolve as children develop their personalities (Eriega, 2014; Collins as cited in Olds and Papilia, 2011). Most of the studies on parenting styles have emphasized that the kind of parenting style adopted by parents has monumental impact on children's attitude, academic achievement, social life and career choice (Maccoby \& Martin 1983). This underscores why children raised in entirely different environments with the same kind of parenting tend to exhibit similar characteristics and behaviours. Different parenting styles produce different characteristic traits of children including those demonstrated at school.

Research suggests that parenting styles and the quality of a parent and adolescent relationship may have an impact on the social development of adolescents. An adolescent's emotions, autonomy, achievement, and identity are all brought about by the parenting style adopted by the adolescent's parent. The manner in which children are raised is crucial to their total development. The way parents respond to children's needs and relate with them has a tremendous impact in the development of their personality and their interaction with society. The family as the first agent of socialization which the child embraces is saddled with the stupendous responsibility of inculcating in the child societal values and skills needed for successful navigation through the different stages of life. It is observed that many adolescents are unable to display social behaviours that could enable them relate with others effectively and enhance their potentials. Social behaviours such as apology, gratitude, assertiveness, commendation and empathy are essential ingredients for peaceful co-existence.

The family is deemed the compass of the child for the exhibition of behaviours that engenders personal growth and harmonious relationship. However, the type of family a child comes from and the parenting styles are capable of influencing the manifestation of social behaviour or antisocial behaviour. Also, the type of family and parenting styles are capable of instilling in the adolescent feelings of high self-esteem, positive self-concept and vice versa. For instance, in many stepparent families stepchildren and stepparents don't always share a cordial relationship. The researcher 
encountered a female adolescent who ran away from house because she felt her stepdad does not love her. This scenario is capable of making the adolescent to have negative self-concept, shyness and feelings of inadequacy. More so, children from single parent family do not have two adult parents which they could model male and female parental social behaviours from. This could make such adolescents to have a female perception of issues if raised by only a female parent and vice versa.

Furthermore, authoritarian parenting which characterized by strict compliance with parental rules is likely to influence guilt, anxiety and dependency in the adolescent and the adolescent would bring these feelings to bare in his relationship with members of society. There is a huge literature on the influence of family types on adolescent's academic achievement. There also exist data on the influence of parenting styles on adolescent deviant behaviour. However, to the best of the researcher's knowledge there is no research on the influence of family types and parenting styles on adolescents' social behaviour in Yenagoa L.G.A. of Bayelsa State. From the foregoing, the problem of this study is to find out the influence of family types and parenting styles on adolescents' social behaviour in Yenagoa L.G.A. of Bayelsa State.

\section{AIM AND OBJectives OF The STUdY}

The aim of thestudy was to examine the influence of family and parenting styles on adolescent's social behaviour. Specifically, the study seeks:-

1. To Find out the extent to which single and step-parent family type influence social Behaviour of adolescent

2. To examine the extent to which authoritative and authoritarian parenting style influence social Behaviour of adolescent

\subsection{Research Questions}

1. To what extent does single and step-parent family type influence social Behaviour of Adolescent?

2. To what extent does authoritative and authoritarian parenting style influence social Behaviour of Adolescent?

\subsection{Hypotheses}

1. There is no significant difference in the influence of single/two parent family on the social behavior of adolescents

2. There is no significant difference in the influence of authoritative/authoritarian Parenting Style on the social behavior of adolescents

\section{ReSEARCh Method And Procedures}

A sample of 383 respondents will be used for the study. This sample size was statistically drawn using Taro Yamen's formula for sample size. The researcher will adopt a simple random sampling technique to select 10 schools from the 18 public schools and purposive sampling technique to determine respondents for the study. Here, the research will purposely select respondents who are within the ambit of the family types the study is interested in, that is, nuclear/extended family and single/two parent family. Two instruments will be used to collect data for the study. Parenting style Inventory II (PSI-II) developed by Darling \& Steinberg (1993) will be adapted and use to collect data relating to parenting styles while Social Behaviour Inventory (SBI) developed by the researcher will be used to collect data on social development of the adolescents.

\section{Data Analysis}

The research questions were answered with mean and standard deviation statistics, while the hypotheses were tested with an independent t-test.

Hypotheses 1: There is no significant difference in the influence of single/two parent family on the social behavior of adolescents

Table4.1. $t$-test analysis on the influence of Nuclear and Extended family on Adolescent Social Behaviour

\begin{tabular}{|l|l|c|l|l|l|l|}
\hline Family Type & $\mathbf{N}$ & $\bar{X}$ & Std.Dev. & Df & Cal-t & P-value \\
\hline Single parent & 192 & 18.13 & 4.55 & 308 & 0.280 & 1.082 \\
\hline Two-parent & 118 & 17.56 & 4.25 & & & \\
\hline
\end{tabular}


In table 4.1, it is shown that the participants from single and two-parent family are numbered 192 and 118 respectively. The adolescents from single parent family had mean score of 18.13 and a standard deviation of 4.55 On the other hand; their counterparts from two-parent family had mean score of 17.56 and SD of 4.25. Based on their mean scores it is deduced that adolescents from single parent family influences social behaviour of adolescents than their counterparts from two-parent family. However when these mean difference was subjected to an independent t-test, a calculated t-value of 0.280 was obtained at a degree of freedom of 308 at 1.082 significant level. Thus since the p-value of 1.082 is greater than 0.05 , the chosen level of probability is decided had insignificant influence on social behavior of adolescents (see table 4.1).

Hypotheses 2: There is no significant difference in the influence of authoritative/authoritarian Parenting Style on the social behavior of adolescents

Table4.2. $t$-test analysis on the influence of Nuclear and Extended family on Adolescent Social Behaviour

\begin{tabular}{|l|l|l|l|l|l|l|}
\hline Parenting Style & $\mathbf{N}$ & $\bar{X}$ & Std.Dev. & Df & Cal-t & P-value \\
\hline Authoritative & 199 & 30.84 & 7.30 & 308 & -5.260 & .000 \\
\hline Authoritarian & 111 & 35.58 & 7.7 & & & \\
\hline
\end{tabular}

In table 4.2, it is shown that the participants from authoritative parents and authoritarian parents are numbered 199 and 111 respectively. The adolescents from authoritative parents had mean score of 30.84 and a standard deviation of 7.33 while their counterparts from authoritarian parents had mean score of 35.58 and SD of 7.7. Based on their mean scores it is deduced that authoritarian parenting style negatively influences social behavior of adolescents than their counterparts. However when these mean difference was subjected to an independent t-test, a calculated t-value of -5.260 was obtained at a degree of freedom of 308 at .000 significant level. Thus, since the p-value of .000 is less than 0.05 , the chosen level of probability is decided had significant influence on social behavior of adolescents; this means that there is a significant difference the influence of authoritative/authoritarian family on the social behavior of adolescents (see table 4.2).

\section{RESEARCH FINDINGS AND DISCUSSION}

\subsection{Single and Step-Parent Family and Adolescents' Social Behavior}

The result of this study showed that, single/step-parent family type does not have significant impact on adolescents' social behaviour. According to the result of this study, the social behaviour of the adolescent is not centred on the type of family the adolescents came from. The result of this study do not also support of that of Maniadaki (2006) who maintained that, many children become distressed when separated from their parents and transfer those anxiety to anyone who tries to settle them into a new sitting. If the adolescents lack social skills, or speech and language problem, this only makes it even worse and stressful.

\subsection{Authoritative/Authoritarian Parenting Style and Social Behavior of Adolescents}

The results of this study revealed that, parenting style (authoritarian/authoritative) have significant influence on the social behavior of secondary school adolescents. The result of the study corroborates that of Steinberg (2001) who opined that, Adolescents from authoritarian families were found to be more dependent and passive. These adolescents were found to be less self-assured and had low selfesteem as well as having weak communication skills (Steinberg, 2001). Darling and Steinberg (1993) also found these adolescents were likely associated with low sociability, obedience, and more likely to be involved in delinquency and substance abuse. Baumrind noted in early childhood children exposed to authoritative parenting were fearful, aggressive, and experienced difficulty in regulating emotions (Baumrind, 1991). Authoritarian parenting can also be associated with behavioral and psychological control. Behavioral control includes structuring the child and tracking behavior in different environments (Barber, 1996). Although adolescents become increasingly focused on social interaction with their peers, parents continue to play an active and important role in the socialization of adolescents' emotions, and the family's emotional climate impacts their well-being. Parents model and mentor their children in the expression and management of emotions, whether positively or negatively. Adolescents whose parents express more negative emotions tend to have more internalizing and externalizing symptoms than those whose parents express fewer negative emotions. 
Youth who receive support from their parents about their negative emotional experiences are better able to discuss negative feelings and talk about strategies for managing them.

Psychological control is an attempt by the parent to control their children through manipulation of thoughts and feelings (Barber, 1996). Behavioral and psychological control has been found to predict very different outcomes in adolescents. Low levels of behavioral control are associated with problems such as antisocial behavior and drug use (Barber \& Harmon, 2002).

High levels of psychological control are linked to anxiety, depression, and withdrawn behavior (Barber \& Harmon, 2002). Based on the parenting styles discussed, it appears an authoritative parent is more likely to express behavioral control while an authoritarian parent is likely to express psychological control. It is important to consider behavioral and psychological control because it may affect an adolescent's development of autonomy and self-regulation (Barber, 1996). Some adolescents may rebel against psychological control over behavioral control thus resulting in negative behavior.

\section{CONCLUSION AND RECOMMENDATIONS}

The study examined family types and parenting styles on the social behaviour of secondary school adolescents. The findings of the study revealed that; family types and parenting styles influence social behavior of secondary school adolescents. Parenting (authoritarian/authoritative) styles significantly influence the social behavior of secondary school adolescents. This was proven to be statistically significant when tested with an independent t-test. Based on the findings of this study, the researcher recommends that, parents ought to be educated on the importance of adopting the parenting style that would aid in promoting their children's development. Educators and counsellors could use fora like PTA meetings, Speech and Prize Giving Days, Open Days and Anniversaries to educate parents on the influence of parenting styles on children's development. Through this, educators would help parents nurture the virtuous child for the millennium.

\section{REFERENCES}

[1] Barber, B. K. (2002). Marital quality, parental behaviors, and adolescent selfesteem. In B. K. Barber \& B. C. Rollings (Eds.), Parent-adolescent interaction (pp. 49-74). Lanham, MD: University Press of America.

[2] Baumrind, D. (1991). "The influence of parenting style on adolescent competence and substance use," The Journal of Early Adolescence, vol. 11, pp. 56-95

[3] Darling, N., \& Steinberg, L. (1993). Parenting style as context: An integrative model. Psychological Bulletin, 113, 487-496.

[4] Eke, P. (2000) social organization and institution, an introduction to Sociology. Choba Port Harcourt, Emhai printing and publishing Inc.

[5] Eriega, G.E (2013) Psychological Foundations of Human Learning Port Harcourt: Abe Publishers Limited.

[6] Maccoby E., and Martin J. (2006). Socialization in the context of the family: Parent-child interaction. In E. M.Hetherington (Ed.), P. H. Mussen (Series Ed.), Handbook of child psychology: Vol.4. Socialization, personality, and social development (pp.100-101). New York: Wiley.

[7] Maccoby, E. E., \& Martin, J. A. (1983). Socialization in the context of the family: Parent-child interaction. In P. Mussen (Ed.), Handbook of child psychology (Vol. 4, pp. 1-101) New York: Wiley.

[8] Macionis, J.J. \& Plummer .K. (2007). Sociology. A global introduction Great Britain Bath Press (1997).

[9] Steinberg, L. (2005). "Adolescence", 9th ed. 101. New York, NY: McGraw-Hill. 


\section{AUTHOR'S BIOGRAPHY}

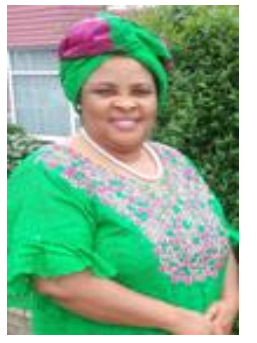

Dr Mrs Rosemary Ekechukwu, is a senior lecturer in the department of Educational Psychology, Guidance and Counselling, Faculty of Education. university of portharcourt. Rivers state. Nigeria. She is a prolific writer. She has authored scholarly articles in reputable international and National Journals. She has attended and presented papers in foreign and local workshops and conferences. She has edited and supervised many undergraduates and graduates students projects, desertations and thesis. She is a member of both local and foreign Researchers, Academics and psychological Associations. Which includes International society of Scientific and Behavioural Development (ISSBD), Counselling Association of Nigeria (CASSON), etc. She is currently working on Mental, Gerontological and community counselling, an area many counselling psychologists neglect.

Citation: Ekechukwu Rosemary Obiagaeri. " Influence of Family Type (Single /Step-Parent) and Parenting Styles (Authoritarian /Authoritative) on Adolescent's Social Behaviour in Yenagoa L.G.A. of Bayelsa State " International Journal of Humanities Social Sciences and Education (IJHSSE), vol 5, no. 1, 2018, pp. 92-97 doi: http://dx.doi.org/10.20431/2349-0381.0501014.

Copyright: () 2018 Authors. This is an open-access article distributed under the terms of the Creative Commons Attribution License, which permits unrestricted use, distribution, and reproduction in any medium, provided the original author and source are credited. 